\title{
Crystals Detail Magma Production and Crust Formation at an Active Back-Arc Submarine Volcano
}

\author{
Teresa Trua ( $\nabla$ teresa.trua@unipr.it) \\ University of Parma \\ Michael P. Marani \\ ISMAR-CNR, Istituto di Scienze Marine \\ Fabiano Gamberi \\ ISMAR-CNR, Istituto di Scienze Marine
}

\section{Research Article}

Keywords: Crystals, magma production, back-arc submarine volcano, Earth's crust formation, chemical evolution, magmatic environments

Posted Date: July 29th, 2021

DOl: https://doi.org/10.21203/rs.3.rs-746707/v1

License: @ (i) This work is licensed under a Creative Commons Attribution 4.0 International License. Read Full License 
Crystals detail magma production and crust formation at an active back-arc submarine volcano

Teresa Trua $^{1^{*}}$ https://orcid.org/0000-0003-0633-5269

Michael P. Marani² https://orcid.org/0000-0003-1853-3975

Fabiano Gamberi² https://orcid.org/0000-0001-7365-8573

1 Department of Chemistry, Life Sciences and Environmental Sustainability, University of Parma, Parco Area delle Scienze 157/A, 43124, Parma. ${ }^{2}$ ISMAR-CNR, Istituto di Scienze Marine, Consiglio Nazionale delle Ricerche, Via Gobetti 101, 40129 Bologna, Italy. *e-mail: teresa.trua@unipr.it

\begin{abstract}
Magmatic reservoirs feed active volcanoes and contribute to Earth's crust formation. Among the processes operating in these systems, those controlling the early chemical evolution stages of magma are the most difficult to identify. This paper reports the first multi-mineral crystal archive that offers insights on the magmatic dynamics governing the production of basalt to andesite lavas at an oceanic back-arc spreading centre. As a result of these dynamics, a mushdominated transcrustal system developed in the last 0.7 million years. The microscale crystal view identifies physicochemical magmatic environments that pass unobserved using whole-rock chemistry alone. It also supplies an interpretative formation model for plumbing system components, functional for the interpretation of geophysical data.
\end{abstract}

Open- to closed-system processes exercise control on the production of magmas erupted at volcanoes, resulting in the construction of complex plumbing systems. Information retrieved from the composition and zoning patterns of crystals carried in erupted lavas significantly contribute to identify the variety of complementary magmatic processes producing the feeding magmas ${ }^{1}$, and provide evidence for the presence of vertically extended magmatic plumbing systems beneath active volcanoes ${ }^{2}$. An igneous crystal viewpoint makes it increasingly apparent that the interplay of these mechanisms passes unobserved under the whole-rock geochemical protocol ${ }^{2}$.

Here we focus on the crystal records preserved in a set of lava samples recovered from the submarine Marsili Volcano (MV), Southern Tyrrhenian Sea, to shed light on the subcrustal magmatic mechanisms that have generated the entire sample suite. The $\mathrm{MV}^{3}$ is a large (c. $70 \mathrm{~km} \times 20 \mathrm{~km}$ ) NNW-SSE elongated seamount that rises from $4000 \mathrm{~m}$ to $500 \mathrm{~m}$ depth along the active spreading centre of the Tyrrhenian Sea (Fig. 1). The Tyrrhenian represents an example of the seafloor spreading stage in a continental back-arc setting ${ }^{4}$, formed following continental crust rifting behind the Aeolian Volcanic Arc and Calabrian suture zone during subduction and retreat of the lonian plate ${ }^{5}$. Magmatic activity of the MV took place in the last 0.7 million years, producing primarily basaltic and basaltic andesite lavas; volumetrically minor andesite lavas were recovered at the summit cone of the volcano $^{6}$ (Fig. 1). The major element variations (Fig. 2a) and the trace element and 


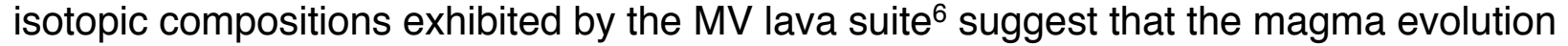
history was controlled by closed-system fractionation of olivine, clinopyroxene, and plagioclase, as basaltic mantle-derived melts are injected into the MV crust cool and differentiate. This crystallization history also recalls the results of the petrological experiments on cooling hydrous basaltic melts simulated in closed-system conditions ${ }^{7}$ (Fig. 2a). Instead, the recent detailed studies of olivine, clinopyroxene and plagioclase crystals carried in the MV lavas ${ }^{8-11}$ have retrieved information on a wide range of opensystem magmatic mechanisms that govern magma evolution within a mush dominated system, where small volumes of melt-rich pockets are spatially and temporally arranged (Fig. 2b).

We combine the diverse records supplied by the MV crystal cargoes to demonstrate that magma genesis is not simply related to cooling following liquidus conditions (Fig. 2a). We show that the petrogenetic indicators supplied by the crystal cargoes capture the more complete spectrum of the physicochemical environments within the transcrustal system (Fig. 2b) feeding cogenetic basic and andesitic magmas.

\section{Results}

Information on the igneous lithologies formed by the MV magmatic activity have been retrieved from both free crystals and those within aggregates found in the erupted lavas ${ }^{8-}$ 11. The mineral assemblage mainly consists of olivine, clinopyroxene, plagioclase and magnetite; rare amphibole-orthopyroxene-plagioclase glomerocrysts were found only in one of the MV basaltic andesite lavas. The glomerocrysts exhibit a variety of mineralogy and textures, from monomineralic (made only by either clinopyroxene or plagioclase crystals, arranged with a locked texture) to polymineralic clusters (made of the mineralogical assemblage described above, with open to locked structures). Overall, the crystal archive is made of minerals crystallizing from the carrier lava with the addition of accidental cogenetic components (antecrysts) of the transcrustal system, extracted by the carrier lava during migration to the surface.

Mineral-melt geothermobarometry calculations coupled with petrological simulations $8,9,11$ constrain the pre-eruptive P-T crystallization conditions during the $0.7 \mathrm{Ma}$ of the MV activity (Fig. 2b). These studies document a crustal lithostratigraphy made of maficultramafic lithologies in the deep crust while gabbroic, at places plagioclase-rich, lithologies dominate at the mid- to upper-crustal levels. A similar crustal structure has been seismically detected along back-arc spreading centres ${ }^{12}$, where crustal lithostratigraphy is defined by applying thermodynamic models to the available whole-rock datasets. The MV crystal archive offers the opportunity to investigate the broad range of processes that play a role in the generation of the back-arc crustal lithostratigraphy.

The MV crystals document a magma solidification history controlled by a crystallization sequence made of olivine-clinopyroxene-plagioclase, similar to the one exposed in exhumed crustal sections of volcanic arcs (e.g. by ref. ${ }^{13}$ ) and obtained by the crystallization experiments on arc melt compositions (e.g. by ref. ${ }^{7,14}$ ). 
In this contribution we interpret the origin of the crystals using the following differentiation indices: forsterite (Fo = $100 \times \mathrm{Mg} /[\mathrm{Mg}+\mathrm{Fe}]$ in mol\%) versus $\mathrm{Ca}(\mathrm{ppm})$ for olivine (Fig. $3 \mathrm{a}$ );

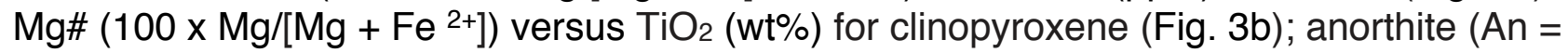
$100 \times \mathrm{Ca} /[\mathrm{Ca}+\mathrm{Na}+\mathrm{K}]$ in mol\%) versus $\mathrm{Mg}$ (ppm) for plagioclase (Fig. 3c). These mineral differentiation indices combine major and minor elements easily accessible with electron microprobe (EMP) and which have different degrees of compatibility during the magmatic crystallization process (e.g. by ref. ${ }^{13,15-18}$ ). Furthermore, we show that plagioclase and clinopyroxene zoning provide more information about magmatic history than olivine zoning. This is due to the slow post-crystallization diffusion re-equilibration rate of An in plagioclase and $\mathrm{Mg \#}$ in clinopyroxene that allows to preserve the original magmatic An and Mg\# zoning, while Fo in olivine generally does not retain this information due to fast diffusional-re-equilibration of $\mathrm{Fe}^{2+}$ and $\mathrm{Mg}$ between olivine and host melt (e.g. by ref. ${ }^{19}$ ).

\section{Discussion}

The pre-eruptive P-T estimates obtained for the MV lavas (Fig. 2b) combined with the information supplied by the record preserved in their crystal cargoes (Fig. 3) constrain several magmatic environments that governed the chemical evolution of the MV lava suite (Fig. 2a).

The first refers to the interconnected mush and melt-rich environments (Fig. $2 b$ ) formed by melt migration mechanisms sourcing basalt to andesite lavas (Fig. 2a). The linear Mg\#-Ti trend defined by the primitive clinopyroxene crystals $(\mathrm{Mg \#}>0.80)$ found in the deep sourced basic lavas (D5 basalt; D1 and D4 basaltic andesites) (Fig. 3b) documents the mafic-ultramafic mush formed by the crystallization stage of hydrous, high-Mg basaltic mantle melts injected at the base of the MV crust (Fig. 2b). Whether this deep crustal mush environment formed by subsidence of cumulates or by in-situ crystallization is of little consequence for this stage. It is noteworthy that the clinopyroxene found in the exposed crustal mush roots of volcanic $\operatorname{arcs}^{13}$ and in lavas sourced from deep crustal mush environments ${ }^{20,21}$ exhibit similar Mg\#-Ti systematics (Fig. 3b).

The D2 basaltic andesite lava sample carries a clinopyroxene cargo that documents crystal growth stage in a melt-rich horizon, formed by melts progressively extracted and collected above the top of the deep crustal mush environment (Fig. 2b). Indeed, the D2 cargo defines a Mg\#-Ti trend where the high Mg\# part overlaps with the most evolved compositions of the D5 clinopyroxene (Fig. 3b), thus suggesting that these primitive crystals formed in melts within interconnected magmatic environments. At lower Mg\# values, the D2 clinopyroxenes split into Ti-depleted and Ti-enriched compositions, pointing towards orthopyroxene and amphibole antecrysts, respectively (Fig. 3b). These antecrysts originate from a mush lithology formed by crystallization of earlier, more evolved hydrous melts stored at the D2 pre-eruptive zone. Some of these antecrysts exhibit a thin clinopyroxene overgrowth rim of evolved composition (i.e., with low Mg\# value), associated to a large range in $\mathrm{Ti}$, documenting the chemical variability of melt in this environment ${ }^{11}$. Clinopyroxene compositions from other amphibole-bearing arc rocks ${ }^{22-24}$ follow the same forked trend (Fig. $3 \mathrm{~b}$ ), showing that this $\mathrm{Mg \# -TiO}_{2}$ clinopyroxene signature identifies the fractionation of amphibole with precursory clinopyroxene in the evolution of arc magmas elsewhere. 
The heterogeneity in the textural and compositional features found in the D2 plagioclase cargo indicates that magma feeding the carrier lava, once extracted from the deep crustal mush environment, migrated through a crustal column consisting of pockets of melt distributed within a crystal-mush framework (Fig. 2b). Indeed, the plagioclase cargo spans the widest and most continuous range of An-Mg compositions, from the An-rich plagioclases found in amphibole-bearing glomerocrysts to the An-poor plagioclases found in monomineralic glomerocrysts (Fig. 3c). It is noteworthy that both have a well-packed texture, characteristic of crystal-rich mush ${ }^{9,11}$. A wide An-Mg compositional range was also found in the plagioclase cargo of the D6 sample (Fig. 3c), a basaltic lava sourced from a mid-crustal storage zone (Fig. 2b). Clinopyroxene crystals are rare in the D6 lava, documenting a further crystallization stage within this environment.

The basalt and basaltic andesite lavas belonging to this magmatic environment contain a diversity of olivine crystals, compatible with an evolutionary path of the magma by melt migration in the envisaged interconnected mush and melt-rich regions ${ }^{10}$. Overall, these olivine cargoes record as much $\mathrm{Ca}$-Fo variation as the regional data set from the nearby Aeolian Volcanic $\operatorname{Arc}^{25}$ (Fig. 3a), but are not able to identify the magmatic processes with the same detail as clinopyroxene and plagioclase.

The mush-melt lens architecture of the MV plumbing system must have survived for sufficient time to sustain the pooling at the base of the volcano edifice of evolved melts (andesitic or more silica-rich) extracted by compaction and percolation from deeper crustal levels (Fig. 2b). Our suggestion is supported by the consideration that the crystal-poor andesite lavas experienced shallow pre-eruptive conditions (Fig. 2b) and carry clinopyroxene with a composition that records growth in melts which had already undergone fractional crystallization at the deep MV crust (Fig. 3b). A recent study 26 speculates that extraction of andesitic melts from a hydrous basic mush system is favoured at a crystallinity window of $50-70$ vol\% and we suggest that a similar scenario sourced the evolved MV melts. As noted by Trua et al. ${ }^{9}$, the occurrence in most of the MV basic lavas of monomineralic plagioclase glomerocrysts with An content lower than those found in plagioclase from andesites (Fig. 3c) provides evidence that andesite lavas are not the most evolved products of the MV magma evolution history.

The second magmatic environment is documented by basaltic magmas rapidly migrating through an already compacted mush portion of the crustal plumbing system. This is recorded by crystals found in high-Mg basalts (Fig. 2a) erupted at the northern sector of the MV (i.e., MRS 1, 2, 3, 4; Fig. 1). This magmatic setting allows the eruption of basaltic magmas almost free of clinopyroxene, with primitive crystals exhibiting a wide range in minor and trace elements (e.g., Ca in Fo-rich olivine; Mg in An-rich plagioclase) (Fig. 3a and c). Olivine and plagioclase crystals strongly zoned in minor elements but buffered at primitive compositions (i.e., high Fo and An contents) have been found in basaltic lavas elsewhere ${ }^{15,16,27}$ and document crystal growth immediately preceding eruption of the carrier magma. These basaltic lavas carry plagioclase cargoes with An-Mg systematics (Fig. $3 c$ ) revealing that the carrier magma briefly stalled in shallow melt lenses before eruption $^{9}$ (Fig. 2b).

A third magmatic environment is that in which hybrid basis lavas formed by magma mixing. It is documented by the crystal cargoes from the D16 basaltic and the D11 and D19 basaltic andesite lavas, all erupted at the off-axis, southeastern flank of the MV (Fig. 1) 
and showing a narrow whole-rock composition (Fig. 2a). Indeed, the large diversity of olivine, plagioclase and clinopyroxene crystals found in these lavas (Fig. 3) supports an ascent history of the carrier magma punctuated by stalling at shallow crustal levels (Fig. 2b). Here, mixing with resident basic magma bodies occurred, favoured by the similar viscosity of the involved basic magmas, thus the hybrid nature of the resulting lavas passes unobserved in their bulk rock chemistry (Fig. 2b).

\section{Conclusion}

The micro-scale view supplied by the MV crystal archive contrasts markedly with the simple closed-system fractional crystallization scenario suggested by the bulk-rock chemistry of the carrier lavas, demonstrating that cogenetic basalt-andesite suites may form by a great variety of open-system magma and crustal accretion dynamics.

This is the first multi-mineral archive that preserves a spectrum of petrogenetic indicators which reconstruct magma emplacement and basalt to andesite evolution scenarios along a $12 \mathrm{~km}$ thick oceanic transcrustal system. These petrogenetic indicators can be used for the interpretation of crystal archives in basaltic-andesite lava suites globally, increasing the ability for decoding the incomplete or cryptic record preserved in crystals. Furthermore, the ability of crystals to identify the distribution of melt rich bodies supplies an interpretative crustal formation model that can be functional for the interpretation of geophysical data at back-arc basins.

Recognising similar scenarios at basaltic-andesite lava suites elsewhere has strong implications for a realistic assessment of magma-crust forming processes.

\section{Data and methods}

The mineral and bulk-rock chemical data are from literature (ref. 8-11). The MV mineral chemical dataset have been collected using the EMP facility (i.e., CAMECA SX50) at the Padova (Italy) branch of the Istituto di Geoscienze e Georisorse of the Italian National Research Council. For a detailed description of analytical conditions refer to the original papers (ref. 8-11).

\section{References}

1. Putirka, K.D. Down the crater: where magmas are stored and why they erupt. Elements 13, 11-16 (2017).

2. Cashman, K.V., Sparks, R.S.J. \& Blundy, J.D. Vertically extensive and unstable magmatic systems: A unified view of igneous processes. Science 355, eaag3055, 10.1126/science.aag3055 (2017).

3. Marani, M.P. \& Trua, T. Thermal constriction and slab tearing at the origin of a superinflated spreading ridge: Marsili volcano (Tyrrhenian Sea). J. Geophys. Res. 107, 2188, 10.1029/2001JB000285 (2002).

4. Vasey, D. A., Cowgill, E., \& Cooper, K. M. A preliminary framework for magmatism in modern continental back-arc basins and its application to the Triassic-Jurassic tectonic evolution of the Caucasus. Geochemistry, Geophys. Geosystems 22, https://doi.org/10.1029/2020GC009490 (2021). 
5. Kastens K. \& Mascle, J. The Geological Evolution of the Tyrrhenian Sea: An Introduction to the Scientific Results of ODP Leg 107. In Proceedings of the Ocean Drilling Program, 107 Scientific Results 107, 3-26 (Ocean Drilling Program, 1990).

6. Trua, T, Marani, P.M. \& Gamberi, F. Magmatic evidence for African mantle propagation into the southern Tyrrhenian back-arc region. Geol. Soc. Amer. Special Paper 478, 307-331 (2011).

7. Melekhova E., Blundy, J., Robertson, R. \& Humphreys, M.C. Experimental evidence for polybaric differentiation of primitive arc basalt beneath St. Vincent, Lesser Antilles. J. Petrol. 56, 161-192 (2015)

8. Trua, T., Marani M. \& Barca D. Lower crustal differentiation processes beneath a back-arc spreading ridge (Marsili seamount, Southern Tyrrhenian Sea). Lithos 190-191, 349-362 (2014).

9. Trua, T, Marani, M. P. \& Gamberi, F. Magma plumbing system at a young back-arc spreading center: The Marsili Volcano, Southern Tyrrhenian Sea. Geochemistry, Geophys. Geosystems 19, 43-59 (2018).

10. Correia da Fonseca, J. V. Magmatic processes within the plumbing system of the Marsili seamount (Southern Tyrrhenian Sea): constraints from the phenocryst cargo of the sampled lavas. PhD thesis, Parma Univ. https://www.repository.unipr.it/handle/1889/4146 (2018).

11. Trua, T. \& Marani, M. Clinopyroxene crystals in basic lavas of the Marsili Volcano chronicle early magmatic stages in a back-arc transcrustal mush system. Geosciences 11, 159, doi.org/10.3390/geosciences11040159 (2021).

12. Eason D. E. \& Dunn, R. A. Petrogenesis and structure of oceanic crust in the Lau back- arc basin. Earth Planet. Sci. Lett. 429, 128-138 (2015).

13. Bouilhol, P., Schmidt, M.W. \& Burg, J.P. Magma transfer and evolution in channels within the arc crust: The pyroxenitic feeder pipes of Sapat (Kohistan, Pakistan). J. Petrol. 56, 1309-1342 (2015).

14. Pichavant, M. \& Macdonald, R. Crystallization of primitive basaltic magmas at crustal pressures and genesis of the calc-alkaline igneous suite: Experimental evidence from St. Vincent, Lesser Antilles arc. Contrib. Mineral. Petrol. 154, 535-558 (2007).

15. Gavrilenko, M. et al. A calcium-in-olivine geohygrometer and its application to subduction zone magmatism. J. Petrol. 57, 1811-1832 (2016).

16. Moore, A., Coogan, L. A., Costa, F. \& Perfit, M. R. Primitive melt replenishment and crystal-mush disaggregation in the weeks preceding the 2005-2006 eruption 950'N, EPR. Earth Planet. Sci. Lett. 403, 15-26 (2014).

17. Ruprecht, P., Bergantz, G. W., Cooper, K. M., \& Hildreth, W. The crustal magma storage system of Volcan Quizapu, Chile, and the effects of magma mixing on magma diversity. J. Petrol. 53, 801-840 (2012).

18. Muntener O., Kelemen, P.B. \& Grove, T.L. The role of $\mathrm{H}_{2} \mathrm{O}$ during crystallization of primitive arc magmas under uppermost mantle conditions and genesis of igneous pyroxenites: An experimental study. Contrib. Mineral. Petrol. 141, 643-658, doi:10.1007/s004100100266 (2001).

19. Bouvet de Maisonneuve, $C$. et al. How do olivines record magmatic events? Insights from major and trace element zoning. Contrib. Mineral. Petrol. 171, 1-20 (2016).

20. Nakagawa, M., Wada, K. \& Wood, C.P. Mixed magmas, mush chambers and eruption triggers: Evidence from zoned clinopyroxene phenocrysts in andesitic scoria from the 1995 eruptions of Ruapehu volcano, New Zealand. J. Petrol. 43, 2279-2303 (2002).

21. Petrone, C.M., Braschi, E., Francalanci, L., Casalini, M. \& Tommasini, S. Rapid mixing and short storage timescale in the magma dynamics of a steady-state volcano. Earth Planet. Sci. Lett. 492, 206-221 (2018).

22. Stamper, C.C., Blundy, J.D., Arculus, R.J. \& Melekhova, E. Petrology of plutonic xenoliths and volcanic rocks from Grenada, Lesser Antilles. J. Petrol. 55, 1353-1387 (2014).

23. Cooper, G.F., Davidson, J.P. \& Blundy, J.D. Plutonic xenoliths from Martinique, Lesser Antilles: Evidence for open system processes and reactive melt flow in island arc crust. Contrib. Mineral. Petrol. 171, 87, doi:10.1007/s00410-016-1299-8 (2016).

24. Larocque, J. \& Canil, D. The role of amphibole in the evolution of arc magmas and crust: The case from the Jurassic Bonanza arc section, Vancouver Island, Canada. Contrib. Mineral. Petrol. 159, 475-492 (2010).

25. Zamboni, D. et al. New insights into the Aeolian Islands and other arc source compositions from highprecision olivine chemistry. Lithos 272-273, 185-191 (2017).

26. Lee, C. T. \& Bachmann, O. How important is the role of crystal fractionation in making intermediate magmas? Insights from Zr and P systematics. Earth Planet. Sci. Lett. 393, 266-274 (2014).

27. Costa F., Coogan, L. A., \& Chakraborty, S. The time scales of magma mixing and mingling involving primitive melts and melt-mush interaction at mid-ocean ridges. Contrib. Mineral. Petrol. 159, 371-387 (2010).

28. Collins, W. J., Murphy, J. B., Johnson, T. E. \& Huang, H.-Q. Critical role of water in the formation of continental crust. Nature Geoscience 13, 331-338 (2020). 


\section{Author contributions}

M.M. and G.F. recovered the lava samples; T.T. interpreted the crystal chemical data; T.T. and M.M. contributed to writing the paper.

\section{Competing interests}

The authors declare no competing interests. 


\section{Figures captions}

Figure 1. Bathymetric map of the Marsili Volcano (modified after $\left.{ }^{9}\right)$. Contour interval 1000 $\mathrm{m}$ (meters below sea level). White, blue and red dots mark the location of lava samples selected for this study, colour-coded for the specific magmatic scenario recorded by the crystal cargo (see Figs. 2 and 3). The inset shows the geological setting of the Southern Tyrrhenian Sea with the location of: the two back-arc basins (Vavilov Basin: VB; Marsili Basin: $\mathrm{MB}$ ) and the Marsili Volcano (red box); the Calabrian Arc suture zone (CA); the Aeolian Volcanic Arc (AVA); the subducting lonian Oceanic Plate (IOP).

Figure 2. Bulk-rock geochemical variation of lava suite from the Marsili Volcano and inferred pre-eruptive conditions. (a) $\mathrm{CaO}$ (wt\%) versus $\mathrm{MgO}(\mathrm{wt} \%)$ diagram showing the compositional spectrum of the Marsili lava suite ${ }^{6}$ compared with the St Vincent Volcano (Lesser Antilles) lava suite field (in green) ${ }^{7}$, reproduced experimentally following shallow ( $P$ $<1 \mathrm{GPa}$ ) crystallization paths from moderately hydrous basaltic melts: olivine-only (black arrow); olivine-clinopyroxene-plagioclase-amphibole (black dashed lines). The Marsili lava samples are colour-coded for the specific magmatic scenario experienced by their crystal cargo (see legend). The grey fields and arrows labelled $\mathrm{Ol}, \mathrm{Cpx}, \mathrm{Pl}$ and $\mathrm{Am}$ refer to compositional data of MV olivine, clinopyroxene, plagioclase, and amphibole from literature ${ }^{8-11}$. (b) P-T diagram with the pre-eruptive storage conditions of the Marsili lava samples (modified after ${ }^{11}$ ). The lithostratigraphy inferred for the feeding transcrustal mushdominated system is schematically illustrated on the right of the diagram. The arrows refer to magma ascent paths, coloured for the varying magmatic scenarios as in the legend in (a). Wet basalt and wet andesite liquidi are from ref. ${ }^{28}$; amphibole (Am) crystallization conditions for the MV lavas (grey field) and Am-out curve are from ref. 8,11 .

Figure 3. Compositional variations of the olivine, clinopyroxene and plagioclase cargoes from the Marsili lavas. The red and blue shading fields and the colourless field with a black rim contain crystal cargoes in lavas (labelled along the field boundary) sourced from the same magmatic environments, as indicated in the legend in (a). The white-dashed lines delimit the crystal compositional variability of the labelled lava samples. (a) $\mathrm{Ca}$ (ppm) versus forsterite (mol\%) in olivine cargoes from basalt and basaltic andesite lavas. Black field represents olivine compositions in primary basaltic melts ${ }^{15}$. Light brown field encloses olivine compositional variations in basic lavas from the nearby Aeolian Volcanic $\mathrm{Arc}^{25}$. (b) $\mathrm{TiO}_{2}$ versus $\mathrm{Mg} /\left(\mathrm{Mg}+\mathrm{Fe}^{2+}\right)$ in the clinopyroxene cargoes from basalt to andesite lavas. The white field marks compositional variations in deep mush-sourced clinopyroxene from arc rocks: basic lavas from Stromboli (Aeolian Volcanic Arc) ${ }^{21}$ and Ruapehu (New Zealand $)^{20}$; exhumed island arc crustal section ${ }^{13}$. Grey field contains clinopyroxene literature data from others amphibole-bearing arc-rocks ${ }^{22-24}$. (c) $\mathrm{Mg}(\mathrm{ppm})$ versus anorthite (mol\%) in plagioclase cargoes from basalt to andesite lavas. Yellow field contains plagioclase literature data for mid-ocean ridge basalts ${ }^{16,26}$. 
Figures

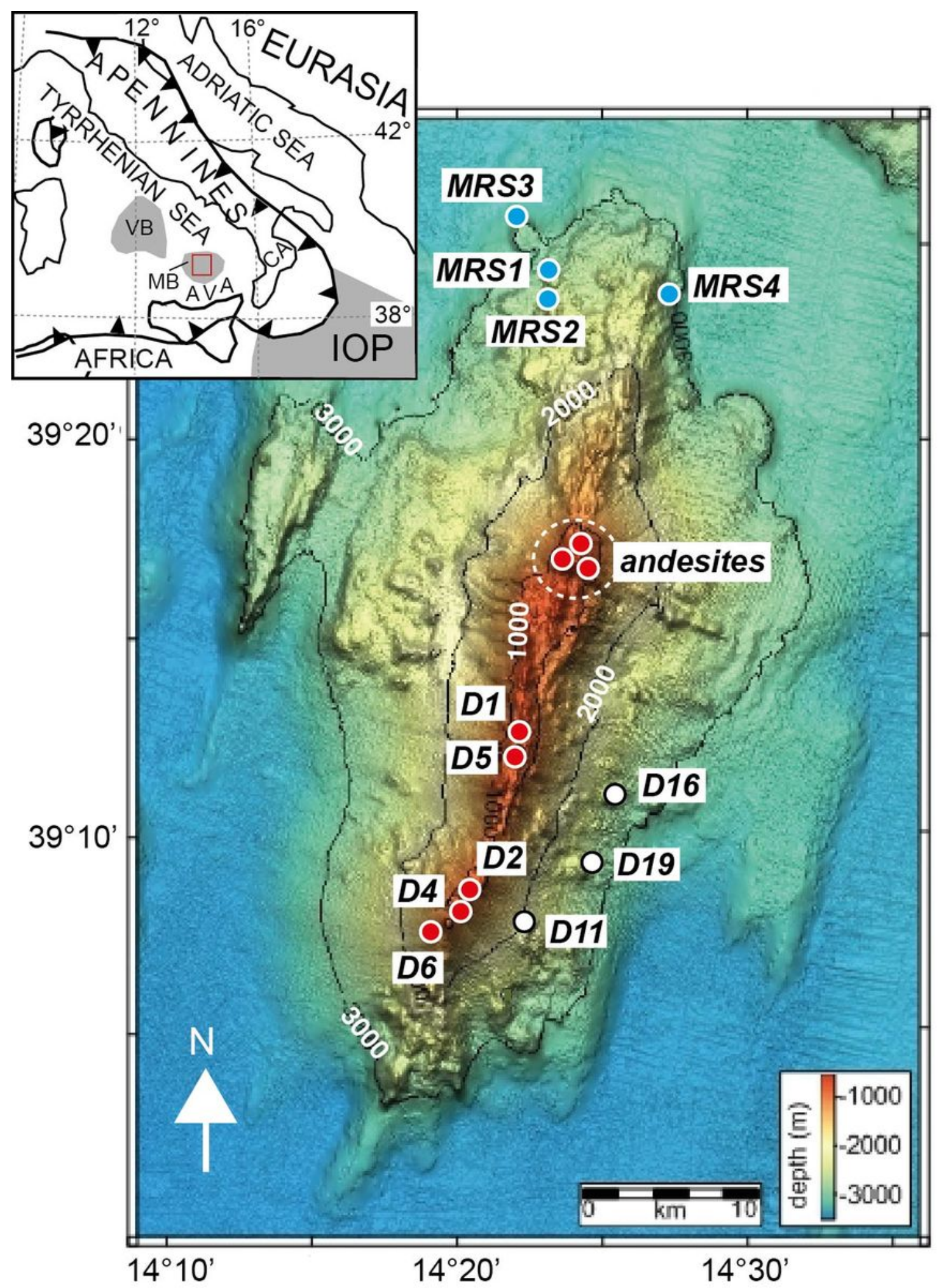

Figure 1

Bathymetric map of the Marsili Volcano (modified after9). Contour interval $1000 \mathrm{~m}$ (meters below sea level). White, blue and red dots mark the location of lava samples selected for this study, colour-coded for the specific magmatic scenario recorded by the crystal cargo (see Figs. 2 and 3). The inset shows the 
geological setting of the Southern Tyrrhenian Sea with the location of: the two back-arc basins (Vavilov Basin: VB; Marsili Basin: MB) and the Marsili Volcano (red box); the Calabrian Arc suture zone (CA); the Aeolian Volcanic Arc (AVA); the subducting Ionian Oceanic Plate (IOP).

(a)
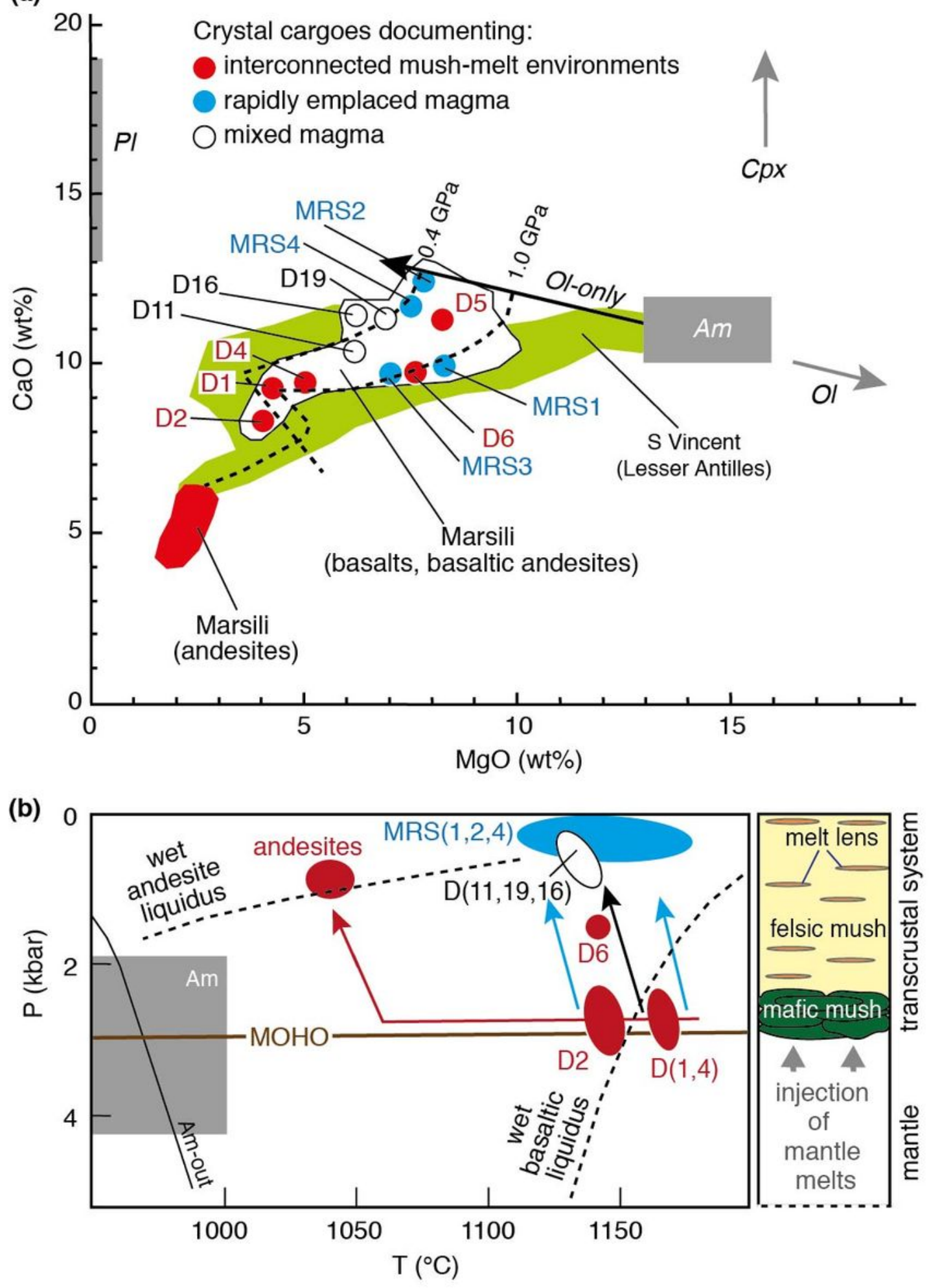

Figure 2

Bulk-rock geochemical variation of lava suite from the Marsili Volcano and inferred pre-eruptive conditions. (a) $\mathrm{CaO}$ (wt\%) versus $\mathrm{MgO}$ (wt\%) diagram showing the compositional spectrum of the Marsili 
lava suite6 compared with the St Vincent Volcano (Lesser Antilles) lava suite field (in green)7, reproduced experimentally following shallow $(\mathrm{P}<1 \mathrm{GPa}$ ) crystallization paths from moderately hydrous basaltic melts: olivine-only (black arrow); olivine-clinopyroxene-plagioclase-amphibole (black dashed lines). The Marsili lava samples are colour-coded for the specific magmatic scenario experienced by their crystal cargo (see legend). The grey fields and arrows labelled $\mathrm{OI}, \mathrm{Cpx}, \mathrm{PI}$ and Am refer to compositional data of MV olivine, clinopyroxene, plagioclase, and amphibole from literature8-11. (b) P-T diagram with the preeruptive storage conditions of the Marsili lava samples (modified after11). The lithostratigraphy inferred for the feeding transcrustal mush-dominated system is schematically illustrated on the right of the diagram. The arrows refer to magma ascent paths, coloured for the varying magmatic scenarios as in the legend in (a). Wet basalt and wet andesite liquidi are from ref.28; amphibole (Am) crystallization conditions for the MV lavas (grey field) and Am-out curve are from ref.8,11. 

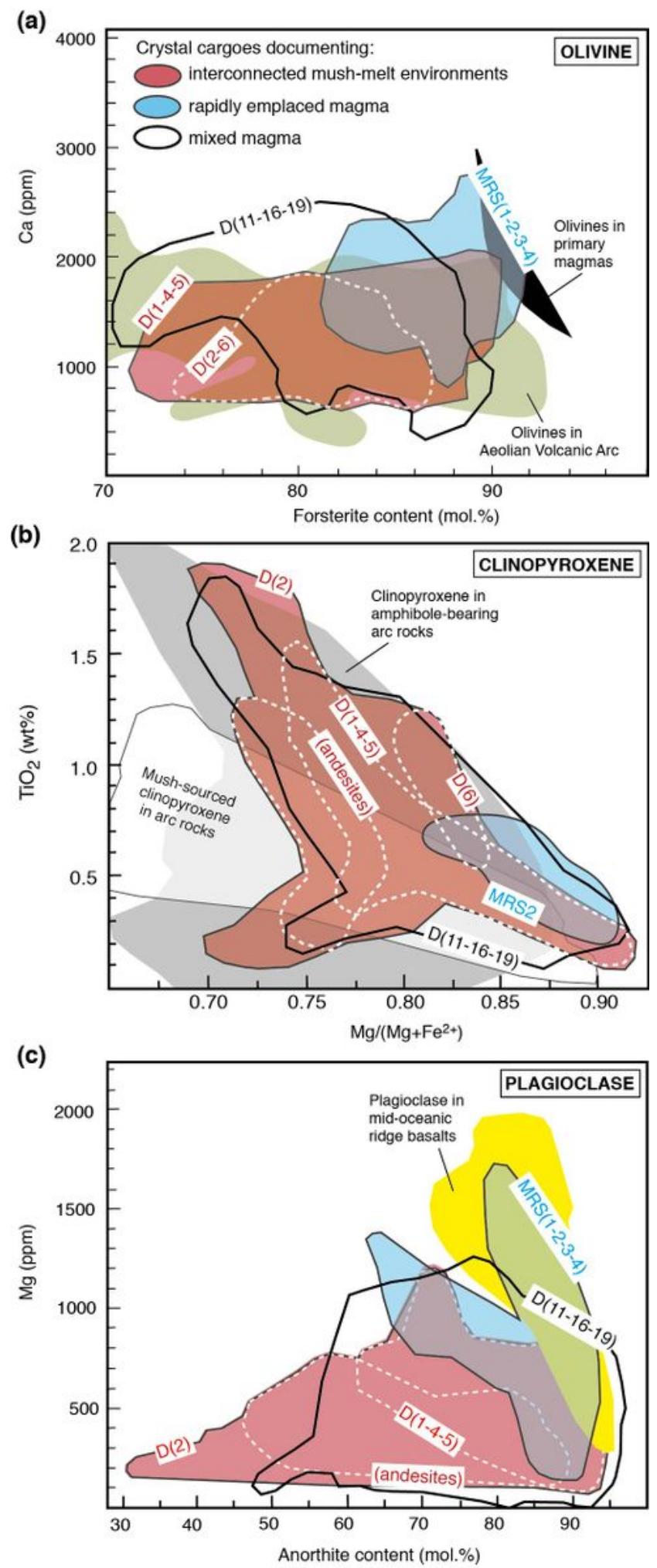

\section{Figure 3}

Compositional variations of the olivine, clinopyroxene and plagioclase cargoes from the Marsili lavas. The red and blue shading fields and the colourless field with a black rim contain crystal cargoes in lavas (labelled along the field boundary) sourced from the same magmatic environments, as indicated in the legend in (a). The white-dashed lines delimit the crystal compositional variability of the labelled lava samples. (a) Ca (ppm) versus forsterite ( $\mathrm{mol} \%)$ in olivine cargoes from basalt and basaltic andesite 
lavas. Black field represents olivine compositions in primary basaltic melts15. Light brown field encloses olivine compositional variations in basic lavas from the nearby Aeolian Volcanic Arc25. (b) TiO2 versus $\mathrm{Mg} /(\mathrm{Mg}+\mathrm{Fe} 2+)$ in the clinopyroxene cargoes from basalt to andesite lavas. The white field marks compositional variations in deep mush-sourced clinopyroxene from arc rocks: basic lavas from Stromboli (Aeolian Volcanic Arc) 21 and Ruapehu (New Zealand)20; exhumed island arc crustal section13. Grey field contains clinopyroxene literature data from others amphibole-bearing arc-rocks22-24. (c) $\mathrm{Mg}(\mathrm{ppm})$ versus anorthite $(\mathrm{mol} \%)$ in plagioclase cargoes from basalt to andesite lavas. Yellow field contains plagioclase literature data for mid-ocean ridge basalts 16,26 . 